\title{
The Relation between Packing Effects and Solid State Fluorescence of Dyes
}

\author{
H. Langhals*, St. Demmig, Th. Potrawa \\ Institut für Organische Chemie der Universität München
}

Abstract. The solid state fluorescence of diketopyrrolopyrrole dyes and perylene-3,4:9,10-tetracarboxylic bisimides with alkyl substituents are investigated and compared with noncovalent interactions. The latter are estimated by crystal structure analysis, heats and entropies of fusion and solubilities in organic solvents. Applications of the dyes are discussed.

\section{Introduction}

The fluorescence of organic pigments is an important subject for practical applications [1] and theory. However, little is known about the relation between crystal structure and solid state fluorescence of dyes [2]. Some dyes, like fluorescein, with very strong fluorescence in solution exhibit only a very poor solid state fluorescence and others, like 5-tert-butylrubicene when crystallized with solvent have a bright solid state fluorescence [3], but not a very strong fluorescence in solution. There is no general theory for these effects.

One model system for these effects is formed by the diketopyrrolopyrroles 1 [4]. Some derivatives are highly fluorescent in the solid state, for example 1 a with $\mathrm{R}=\mathrm{CH}_{3}$, aryl = 3,5-di-tert-butylphenyl or $\mathbf{1}$ b with $\mathrm{R}=\mathrm{C}_{2} \mathrm{H}_{5}$, aryl $=3$,5-di-tertbutylphenyl or 1 c with $\mathrm{R}=\mathrm{CH}_{3}$, aryl $=2$-methylphenyl. Other derivatives, such as $1 \mathrm{~d}$ with $\mathrm{R}=\mathrm{H}$, aryl = 2-methylphenyl, are only weakly fluorescent [5]. The o-methoxyderivative o- $\mathrm{CH}_{3} \mathrm{O}$-DPP $1 \mathrm{e}$ is a link between the two series, for it crys-<smiles>O=C1NC(=O)C2[NH+]C(=O)C(Br)=C12</smiles>

1

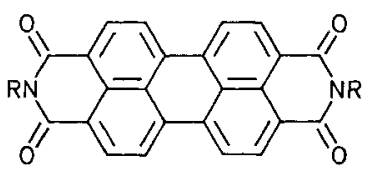

$2 \mathrm{R}=\mathrm{CH}_{-\mathrm{R}^{\prime}}^{-\mathrm{R}^{\prime}}$

$3 \mathrm{R}=\mathrm{CH}_{2}-\mathrm{R}^{1}$

\begin{tabular}{|c|c|}
\hline & $R^{\prime}$ \\
\hline & $\mathrm{n}-\mathrm{C}_{3} \mathrm{H}_{7}$ \\
\hline & $\mathrm{n}-\mathrm{C}_{4} \mathrm{H}_{9}$ \\
\hline & $n-C_{5} H_{11}$ \\
\hline & $n-C_{6} H_{13}$ \\
\hline & $\mathrm{n}-\mathrm{C}_{7} \mathrm{H}_{15}$ \\
\hline & $\mathrm{n}-\mathrm{C}_{8} \mathrm{H}_{17}$ \\
\hline & $\mathrm{n}-\mathrm{C}_{9} \mathrm{H}_{19}$ \\
\hline & $\mathrm{n}-\mathrm{C}_{10} \mathrm{H}_{21}$ \\
\hline & $\mathrm{n}-\mathrm{C}_{12} \mathrm{H}_{25}$ \\
\hline & $\mathrm{n}-\mathrm{C}_{13} \mathrm{H}_{27}$ \\
\hline & $\mathrm{n}-\mathrm{C}_{15} \mathrm{H}_{31}$ \\
\hline & $n-C_{16} H_{33}$ \\
\hline & $n-C_{17} H_{35}$ \\
\hline & $n-C_{18} H_{37}$ \\
\hline
\end{tabular}

$1 \mathrm{e}$ 
tallizes in two modifications, the thermodynamically stable $1 \mathbf{A}$ with a strong solid state fluorescence and the metastable $1 \mathbf{B}$ with only a weak solid state fluorescence. The crystal structure analysis has been performed with both modifications [5] so that there is the complete information about lattice packing. In the weakly fluorescent $1 \mathbf{B}$ the chromophores are stacked one over the other, as shown in Fig. 1, so that there are strong interactions between the chromophores. We think that these interactions will not only cause a bathochromic shift in the solid state absorption but also a rather strong coupling of the electronic energy to lattice vibrations. This coupling can enhance an energy transfer to lattice vibrations and thus quenching of fluorescence may occur. In $\mathbf{1} \mathbf{A}$ the chromophores are laterally shifted so that there is only little interaction. As a consequence, excitation energy persists until fluorescence.

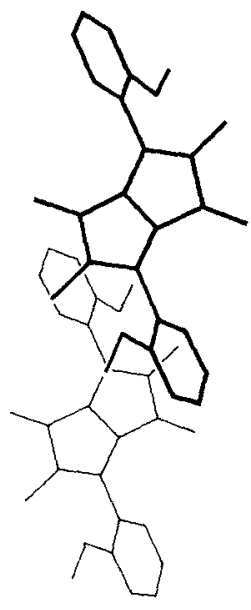

$1 \mathrm{~A}$

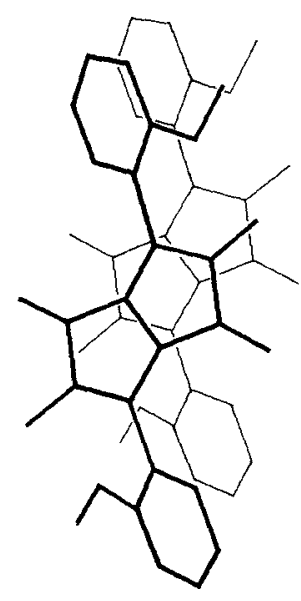

$1 B$

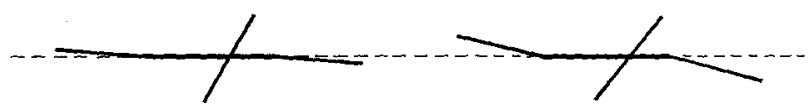

Fig. 1 Stacking of the chromophors in $1 \mathrm{~A}$ and $1 \mathrm{~B}$.

\section{Results and Discussion}

The strength of the chromophor-chromophor interaction in $\mathbf{1 B}$ is demonstrated by a comparison of the molecular structures in the two modifications. Whereas the o-methoxyphenyl substituent in $1 \mathrm{~A}$ is turned out of the plane by $59.2^{\circ} \mathrm{C}$ and has the expected geometry with carbon-carbon bonds of nearly equal length, the substituent in $\mathbf{1 B}$ is compressed further into the plane with a remaining angle of only 
$50.7^{\circ} \mathrm{C}$. As the non-bonding distances of the $\mathrm{N}$-methyl carbon and nitrogen to the oxygen of the methoxy group are not changed, the bond angles in the phenyl substituent are deformed by the lattice forces. These forces are so high that the methyl group at the nitrogen is bent out of the plane by about $14^{\circ}$, whereas in $1 \mathbf{A}$ it remains nearly in plane $\left(4^{\circ}\right)$. The strong compression of the molecule is further indicated by the slightly higher density of the metastable 1 B with $\varrho=1.382 \mathrm{~g} \cdot \mathrm{cm}^{-3}$ compared to $1 \mathrm{~A}$ with $\varrho=1.281 \mathrm{~g} \cdot \mathrm{cm}^{-3}$.

As a consequence of the deformation of the rings, there are substantial changes in the IR-spectra. For example for $1 \mathrm{~A}$ a carbonyl absorption is observed at $1677 \mathrm{~cm}^{-1}$ $(\mathrm{KBr})$, whereas the absorption of $1 \mathrm{~B}$ is shifted to $1682 \mathrm{~cm}^{-1}$. This shift to higher wavenumbers is caused by the bending of the methyl groups at the nitrogens out of the plane which decouples partially the conjugation of the nitrogen atoms with the carbonyl groups.

A second model system for the investigation of these effects is given by the perylene dyes (2), perylene-3,4:9,10-tetracarboxylic bisimides. These dyes are very photostable and strongly fluorescent in solution [6-9], so that they can be used for laser [10-12], fluorescent planar concentrator [13] and for analytical [14-17] applications. The fluorescence is influenced only very little by substituents on the nitrogens. This might be caused by nodes [18] in the wave functions of the $\pi$ orbitals at the nitrogens not only in HOMO and LUMO, but even in the orbital above LUMO and below HOMO. Because of the small influence of the substituents at the nitrogens on optical properties the perylene dyes are an ideal probe for studying crystal packing effects with different $\mathrm{N}$-substituted derivatives.

The solid state fluorescence of these dyes is not as pronounced as in solution. There are two major types of pigments with the chromophor 2 , a black-blue one with no visible fluorescence and a red one with a weak, red fluorescence. Furthermore, a few maroon and orange coloured pigments are known. Crystal structure analysis done with both major types of pigments [19-22] indicate that the chromophores are parallel stacked and laterally displaced.<smiles>[R]N1C(=O)c2ccc3c4ccc5c6c(ccc(c7ccc(c2c37)C1=O)c64)C(=O)N([R])C5=O</smiles>

2

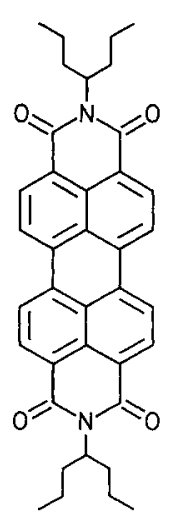

2a

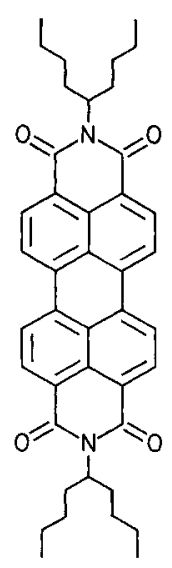

$2 \mathbf{b}$<smiles>CCCCCC(CCCCC)N1C(=O)c2ccc3c4ccc5c6c(ccc(c7ccc(c2c37)C1=O)c64)C(=O)N(C(CCCCC)CCCCC)C5=O</smiles>

$2 \mathrm{c}$ 
An exception thereto is dye $\mathbf{2}$ b with two 1-butylpentyl substituents at the nitrogens, which has a brilliant red solid state fluorescence that makes it useful as a fluorescent marker [26]. This solid state fluorescence is remarkably stronger than that of the longer chain homologue $2 \mathbf{c}$ with 1-pentylhexyl substituents as well as that of the shorter chain homologue $\mathbf{2}$ a with 1-propylbutyl substituents. Unfortunately, ordered single crystals could not be prepared for studying packing by crystal structure analysis. However, it could be shown by x-ray powder diffraction that $\mathbf{2 a}, \mathbf{2 b}$ and $\mathbf{2 c}$ are crystalline. The differences in packing become obvious by the application of mechanical stress to the powders. While the crystalline structure of $2 \mathrm{a}$ and $2 \mathrm{c}$ persists with pulverisation (as well as the one of $1 \mathrm{~A}$ and $\mathbf{1 B}$ ) the fluorescent $\mathbf{2 b}$ becomes amorphous. We think that strong interactions of the chromophores are not only the basis of the rather stable crystalline structure of $2 \mathbf{a}$ and $2 \mathrm{c}$ but are also responsible for the fluorescence quenching via the coupling of electronic excitation to lattice vibrations. However in the highly fluorescent $\mathbf{2} \mathbf{b}$ the chromophore-chromophore interactions are weak: resulting both in a brilliant solid state fluorescence and in a breakdown of lattice structure on the application of mechanical stress.

The concept of relations between lattice packing and solid state fluorescence is strongly supported and extended by the investigation of a further type of packing in perylene fluorescent dyes, an example for which is dye $\mathbf{2} \mathbf{g}$ (with two 1-octylnonyl substituents at the nitrogens). This dye has not only an orange colour, but in contrast to the other perylene dyes has an extraordinarily intense orange solid state fluorescence which resembles the fluorescence of perylene dyes in diluted solutions.

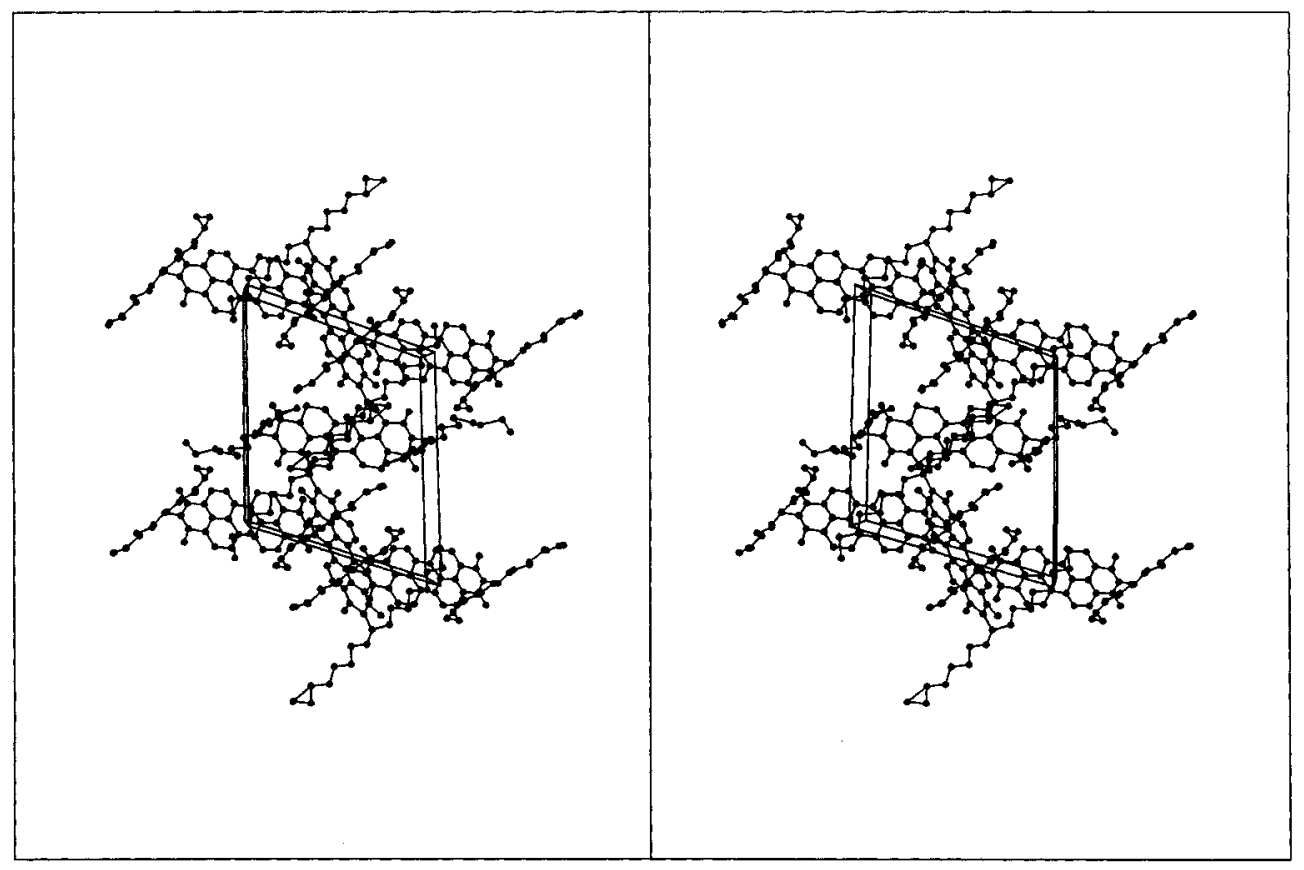

Fig. 2 Structure and crystal packing of perylene dye $\mathbf{2} \mathbf{f}$. 
Crystals of the dyes are neither very ordered nor densely packed - a problem is the flexibility of the alkyl side chains. On the other hand, the exact geometry of the side chains is not important for the discussion of chromophore-chromophore interactions. A single crystal structure determination could be done measuring 18000 reflexes with 4000 observed ones. The obtained $R$ value of $26 \%$ is high enough for the localisation of the chromophores. The packing is given in Fig. 2. One layer in the structure is formed by the planes of the chromophores. In the next layer the chromophores are nearly orthogonal to those in the first layer but laterally shifted, thus the alkyl side chains are in the first plane. The third layer corresponds again to the first one. The packing is like a sandwich of chromophores with alkyl chains between them. The chromophores are isolated by paraffin chains and the optical properties of the dye are similar to those in diluted petrol ether solution.

Dye $2 \mathrm{f}$ has another interesting property: a change in colour from orange to red several degrees below melting point. This is even more pronounced with dye 1e which has a 1-heptyloctyl substituent. At $50-60^{\circ} \mathrm{C}$ the colour of the solid changes abruptly from orange to red with a weaker red fluorescence. We think that this change in optical properties is caused by a change in the crystal to the structure of the red perylene pigments mentioned above. This will be the subject of further investigations. On the other hand, this change in modification can be used for optical information storage [23-25] in such a way that information is written in by a laser beam which induces a thermal transformation of the modifications and is read out by the detection of the fluorescence of dye $1 \mathbf{e}$.

Packing effects and chromophore-chromophore interactions determine the lattice energy of the pigments. One way to get information about these effects is to measure the solubility of homologous series of dyes. The solubility is influenced both by lat-

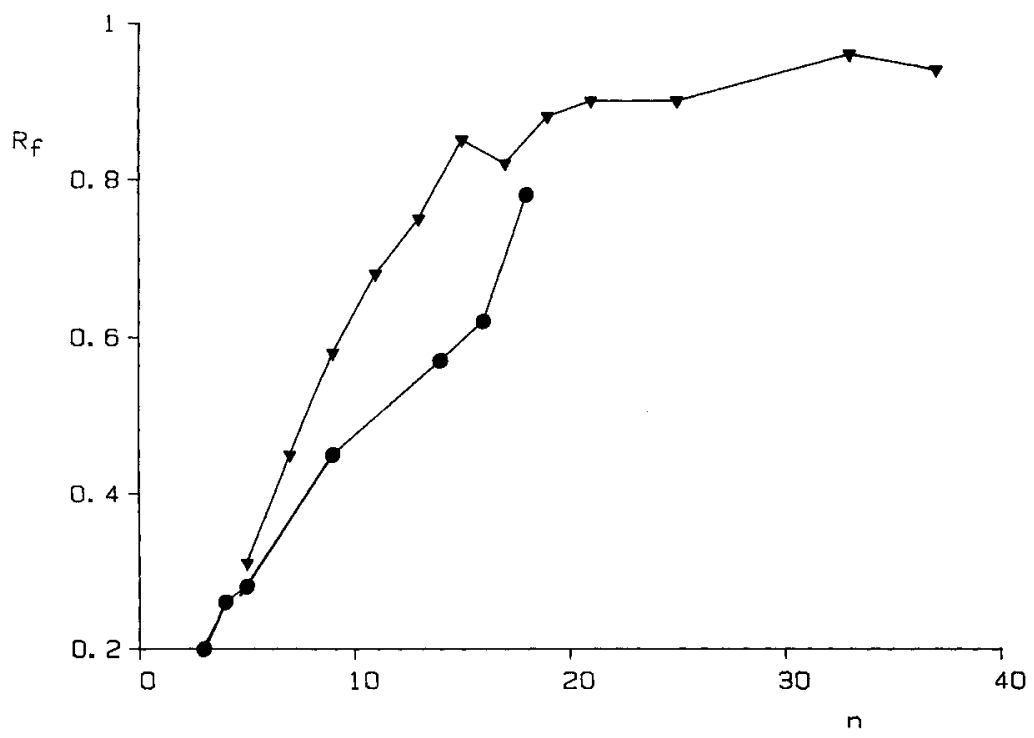

Fig. 3 TLC $-\mathbf{R f}-$ values of perylene dyes (2) with $R=$ alkyl as a function of chain length $n$ (silica $\left.\mathrm{gel} / \mathrm{CHCl}_{3}\right) \cdot \bullet \mathrm{n}-$ alkyl, $\checkmark: \mathrm{sec}-$ alkyl with substitution at position $(\mathrm{n}-1) / 2$. 


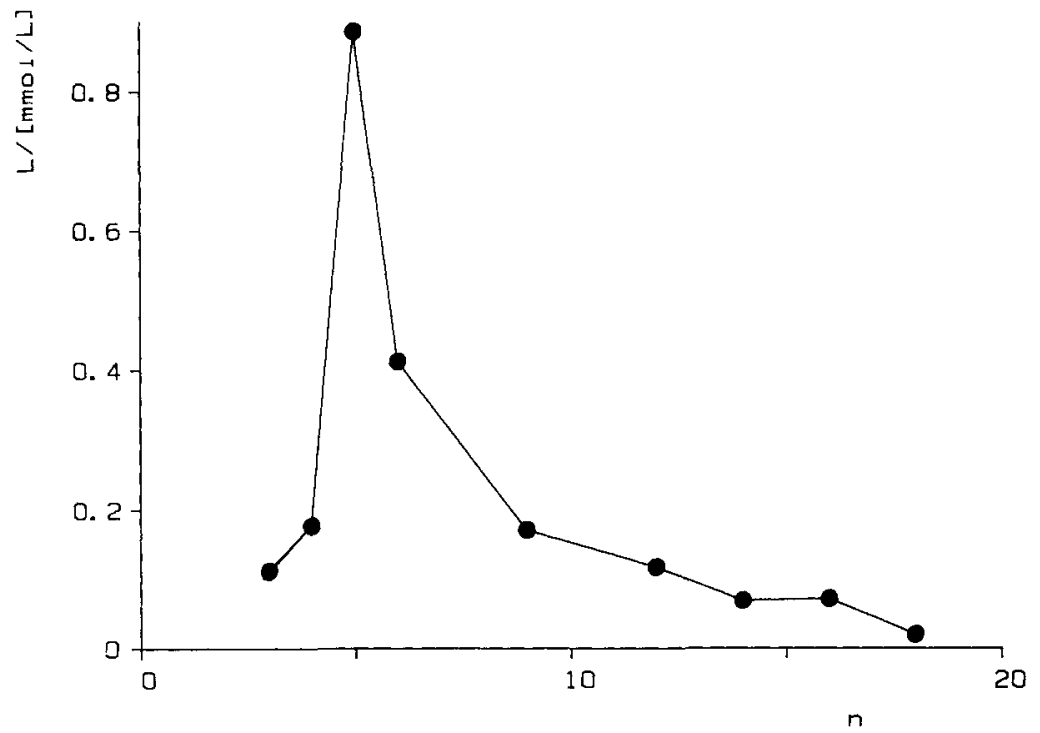

Fig. 4 Solubility of perylene dyes (2) with $\mathrm{R}=\mathrm{n}-$ alkyl as a function of chain length $\mathrm{n}$ (in $\mathrm{CHCl}_{3}$ at $20^{\circ} \mathrm{C}$ ).

tice energy and solvation effects. The latter vary essentially monotonically with chain lengths. This is indicated for the perylene dyes by the continuous change in TLC-Rf-Values as a function of chain length as given in Fig. 3. A further indication

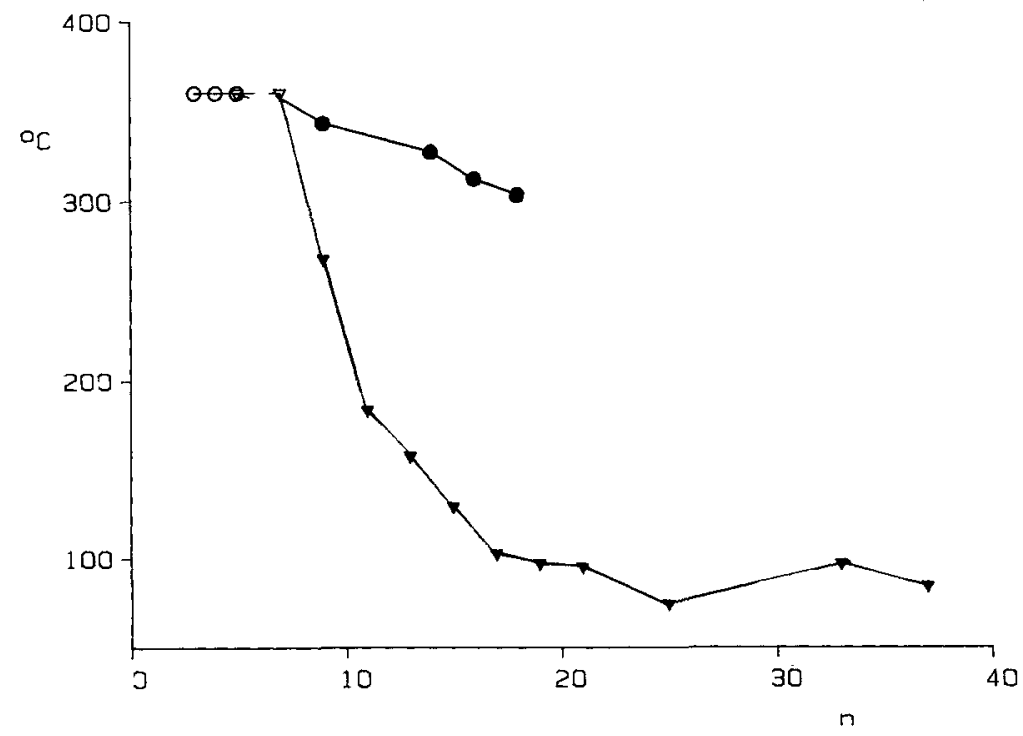

Fig. 5 Melting points of perylene dyes (2) with $\mathrm{R}=$ alkyl as a function of chain length $\mathrm{n} . \bullet: \mathrm{n}-$ alkyl, $\checkmark$ : two $1-n-$ alkyl groups at a $\mathrm{N}$-bounded methylene group. Substitution at position $(\mathrm{n}-1) / 2$. Unfilled circles and triangles for melting points $>360^{\circ} \mathrm{C}$. 
is given by the ${ }^{13} \mathrm{C}$-NMR spectra of the dyes. The chemical shifts of the nearest three carbon atoms of the side chains to the link with the nitrogen atoms are independent from chain length within experimental error, and one must conclude that the influence of the chromophore is independent of chain length and the side chains form statistically oriented clusters in any case in diluted solution. Therefore the solubilty of the pigments in these series is a good measure for the free energy of packing and is used for getting more information.

The solubility of perylene dyes 2 with n-alkyl substituents as a function of chain length is given in Fig. 4. There is a maximum of solubility at $n=5$ with a still low absolute value and then a continuous decrease of solubility with longer chains. We believe that there are basically two opposing effects. The high lattice energy built up by the interaction of the perylene dye chromophore ( 2 with $\mathrm{R}=\mathrm{H}$ is nearly insoluble in any solvent) is disturbed by the increasingly flexible alkyl side chain up to a chain length of 5 resulting in an increasing solubility. Then, with $n>5$ the structure is dominated by ordering of the side chains as in paraffins. This tendency is indicated by the dependence of the melting points of the dyes on the length of the alkyl chain; filled circles in Fig. 5. Although the solubilities decrease with greater chain length for $\mathrm{n}>5$ the melting points decrease too; for a more detailed discussion see below.

A completely different dependance of solubility on the number of carbon atoms is obtained, when $\mathrm{R}=$ cycloalkyl as shown in Fig. 6 . The dye with cyclopropyl substituents has a very low solubility in organic solvents. The solubility goes through a maximum for $\mathrm{R}=$ cyclopentyl and then drops to very small values for $\mathrm{R}=$ cyclooctyl. Then the solubility increases again and reaches a maximum with $\mathbf{R}=$ cyclotetradecyl, which is a very soluble dye. With even larger rings the solubility decreases again. The decrease of the solubility of the dyes with larger rings systems is inter-

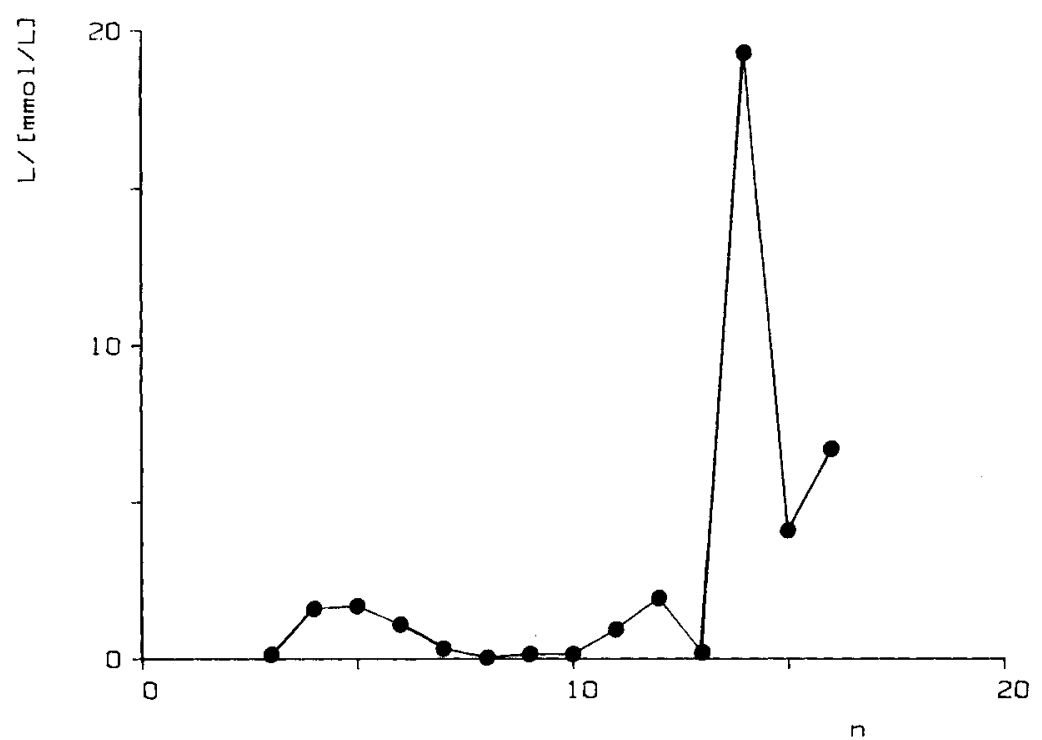

Fig. 6 Solubility of perylene dyes (2) with $\mathrm{R}=$ cycloalkyl as a function of the number $\mathrm{n}$ of ring carbons (in $\mathrm{CHCl}_{3}$ at $20^{\circ} \mathrm{C}$ ). 


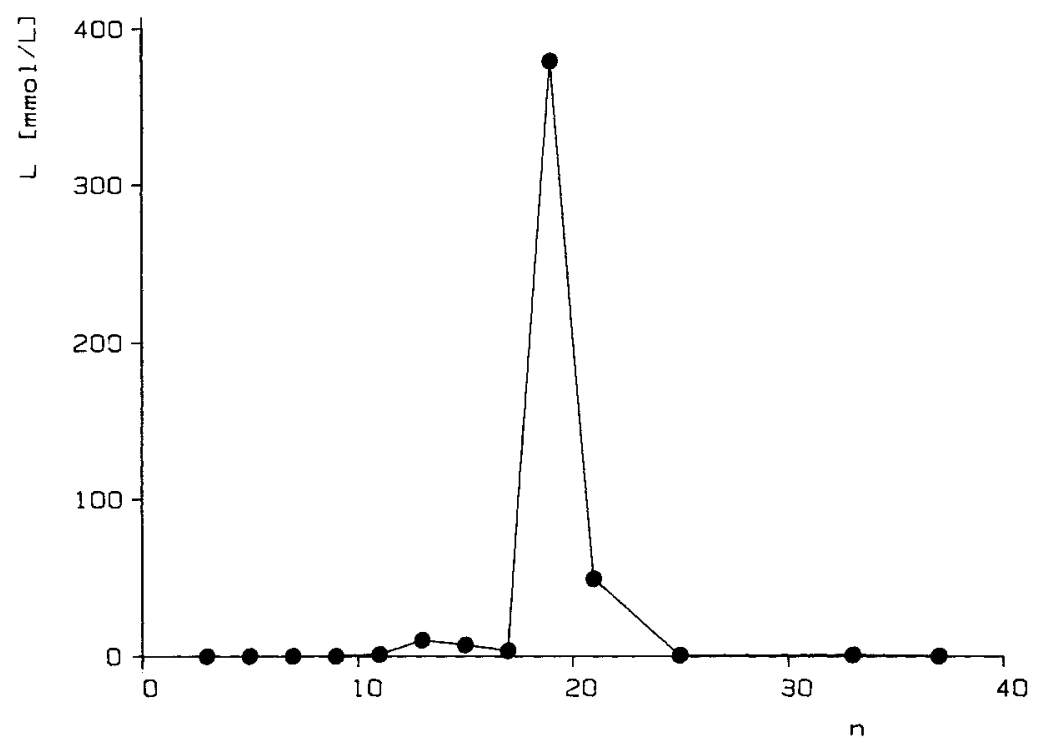

Fig. 7 Solubility of perylene dyes (2) with two $1-\mathrm{n}$-alkyl groups at a $\mathrm{N}$ - bounded methylene group. Chain length $n$. Substitution at position $(n-1) / 2$ (in heptane at $20^{\circ} \mathrm{C}$ ).

preted in the same way as with n-alkyl substituents. Large membered rings have mainly the conformation of two parallel alkyl chains. Therefore an interesting test

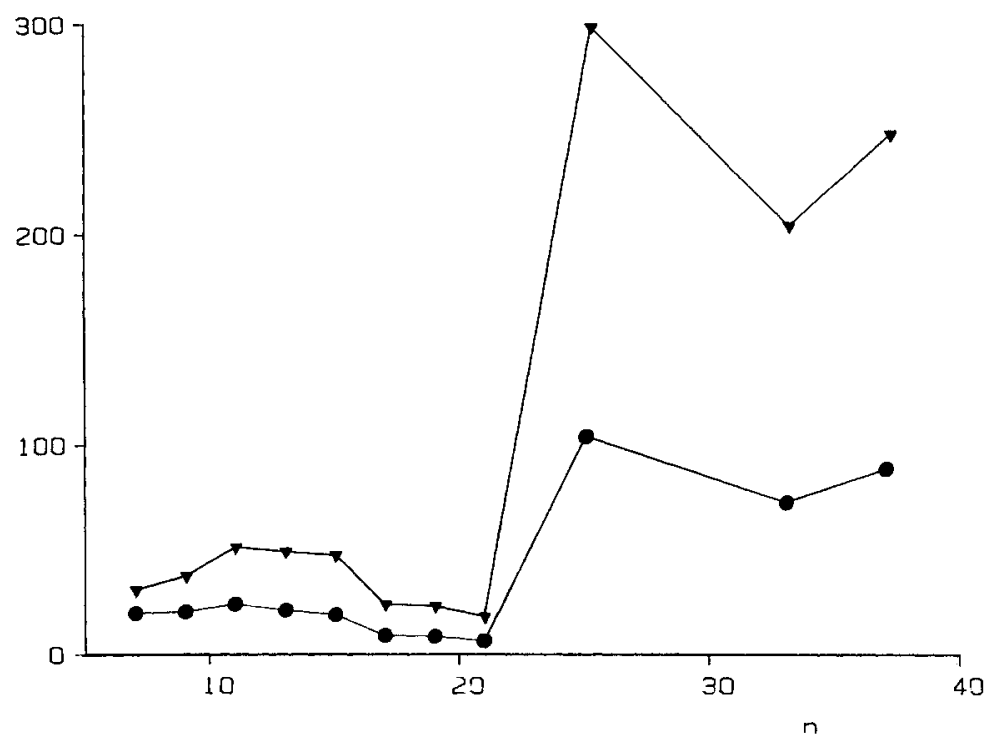

Fig. 8 Energies of fusion $(\bullet)$ in $\mathrm{kJ} / \mathrm{mol} / \mathrm{mol}$ and entropies of fusion $(\nabla)$ in $\mathrm{J} . \mathrm{mol}^{-1} \mathrm{~K}^{-1}$ of perylene dyes (2) with two $1-n-$ alkyl groups at the $\mathrm{N}$ - bounded methylene group. Chain length $\mathrm{n}$. Substitution at position $(n-1) / 2$. 
for the interpretation is to cut the connection between these two "chains" at the point opposite to substitution and to investigate secondary alkyl substituents with two 1-n-alkyl groups at the N-bounded methylene group.

The solubility of this homologous series is shown in Fig. 7. There is an exponential increase in solubility with the chain length. The solubility is so high, that $\mathrm{CHCl}_{3}$ must be replaced for measurements by less solvating heptane. In this solvent the exponential increase reaches a flat maximum with a high value for $n=13$, and then an extreme peak solubility for $n=19$. With even longer chains the solubility drops again to small values. This complex behaviour of homologues is further investigated by the measurement of melting points as a function of chain length; filled triangles in Fig. 6. Although there is a peak solubility for $n=19$ the melting points decrease continuously to the melting points of paraffins indicating that the molecular interactions are becomming more and more similar to the ones in long chain alkanes. Even more information about these effects is given by the measurement of the energies for fusion as shown in Fig. 8.

The energy is low for short chain derivatives, passes a flat maximum for $\mathbf{n}=11$ and decreases to $8 \mathrm{~kJ} / \mathrm{mol}$ for $\mathrm{n}=21$. Then there is an abrupt jump to high values of about $80 \mathrm{~kJ} / \mathrm{mol}$ for long chain substituents.

The entropy of fusion gives a similar result; see Fig. 8. Again, a flat and not pronounced maximum is found for $\mathrm{n}=11$, a non-pronounced minimum for $\mathrm{n}=21$ with $4 \mathrm{e}$. u. and then a sharp jump to values of about $60 \mathrm{e} . \mathrm{u}$. for long chain substituents. Further data are given in Table 1.

These results are interpreted in terms of order in crystal structure. Short chain alkyl perylene dyes form crystals which are dominated by the forces of interaction of the chromophores. Therefore the melting points are high, but the differences in the bulk structures of the improperly packed solids and partially oriented melts of these flat, rigid molecules are not very pronounced; this is further indicated by the difficulties in single crystal structure analysis of these dyes, although large single crystals can be prepared. However liquid crystalline states could not be detected by D.S.C.. So the energy of fusion is low as well as the entropy of fusion. With longer alkyl chains the order of the crystals is further disturbed by the chains so that the energy tends to decrease further until $n=21$. However for longer chains, $n>21$, there is a abrupt change, for now the interactions of the alkyl side chains become dominant with a transition of the side chains to a paraffin-like crystal which has order, and a molten material with statistically oriented clusters of side chains. This results in a high energy of melting and a high entropy.

This interpretation is further supported by the fact that there are many solid-solidphase-transitions for $n<21$ which have energies in the range of the energy of fusion or even higher; see Table 1. So the energetic effects of melting are not very pronounced for these dyes in contrast to the longer chain homologues. A further indication of the low preference for ordered structures of these dyes is the already mentioned fact that for $\mathrm{n}=9 \mathrm{a}$ complete breakdown of crystal structure can be obtained by merely pulverizing the dye.

The reported solid state properties of the dyes are interesting for practical applications. For $\mathrm{n}=15 \ldots 25$ small external influences should be able to switch one structure into the other. This is of interest for aggregation of dyes and applications in micelles and liposomes. These future results will be reported elsewhere. 

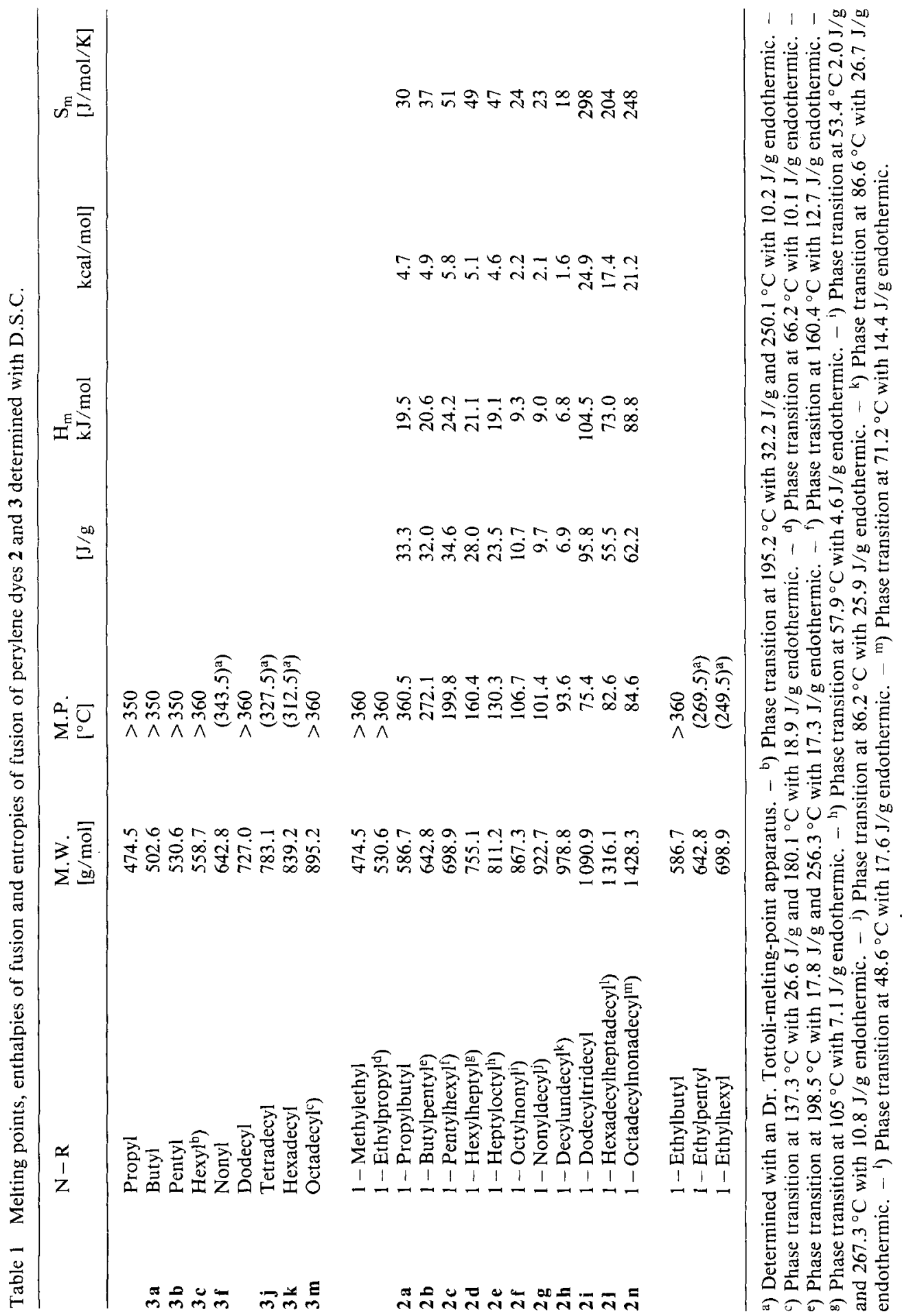
Acknowledgement: This work was supported by Deutsche Forschungsgemeinschaft und Fonds der Chemischen Industrie. We thank Consortium für Elektrochemie of Wacker AG for a gift of cyclohexadecanone, Hilti Entwicklungs-GmbH for help with the DSC/DTA measurements, Dr. KARL PETERS for X-ray single crystal diffraction, Prof. Dr. GÜNTER NAGORSEN for X-ray powder diffraction and Mss. MARIE SCANDONE from Sadtler Research Laboratories for the information about differences in the i.r.-spectra of 1 A (Ref. No. 79941) and 1 B (Ref. No. 79942).

\section{Experimental}

The perylene dyes have been prepared from perylene-3,4:9,10-tetracarboxylic bisanhydride, the corresponding amine or amine hydrochloride $(6 \mathrm{mmol})$ and imidazol $(5 \mathrm{~g})$ and have been purified exactly according to literature procedure $[8,9,26]$. Special care has been taken to prepare highly pure dyes. The perylene dyes (3) with $\mathrm{R}=1$-hexyl, 1-dodecyl, 1-octadecyl, cycloalkyl up to cyclopentadecyl, and secalkyl up to 1-hexylheptyl are described in ref. [9]. The solubilities of the perylene dyes are determined after a one week contact of the solution with the solid dye with occasional shaking. The enthalpies of fusion are determined by D.S.C. with indium as a standard (Metter DTA 810). The entropies of fusion are calculated from enthalpies and melting points.

\section{N,N'-Di(1-propyl)perylene-3,4:9,10-bis(dicarboximid) [27]}

$0.35 \mathrm{~g}(6.0 \mathrm{mmol}) 1-P r o p y l a m i n$, reaction time $1 \mathrm{~h}$, purification by extractive [8] recrystallisation from toluene. Yield $1.12 \mathrm{~g}(93 \%)$, black needles $-\mathrm{mp} .>350^{\circ} \mathrm{C}, \mathrm{R}_{\mathrm{f}}$ (silica gel $\left./ \mathrm{CHCl}_{3}\right)=0.20$. $\mathrm{IR}$ $(\mathrm{KBr}): \tilde{\nu}=2964 \mathrm{~cm}^{-1} \mathrm{~m}, 2934 \mathrm{w}, 2874 \mathrm{w}, 1695 \mathrm{~s}, 1663 \mathrm{~s}, 1616 \mathrm{w}, 1594 \mathrm{~s}, 1579 \mathrm{~m}, 1507 \mathrm{w}, 1482 \mathrm{w}$, $1458 \mathrm{w}, 1441 \mathrm{~m}, 1404 \mathrm{~m}, 1378 \mathrm{~m}, 1342 \mathrm{~s}, 1251 \mathrm{~m}, 1206 \mathrm{w}, 1179 \mathrm{w}, 1156 \mathrm{w}, 1127 \mathrm{w}, 1082 \mathrm{w}, 1013 \mathrm{w}$, 1003 w, 963 w, 885 w, $863 \mathrm{w}, 852 \mathrm{w}, 810 \mathrm{~m}, 797 \mathrm{w}, 788 \mathrm{w}, 745 \mathrm{~m}, 631 \mathrm{w}, 589 \mathrm{w}$. - UV $\left(\mathrm{CHCl}_{3}\right): \lambda_{\max }$ $(\epsilon)=457.5 \mathrm{~nm}(17310), 488(47380), 524(78730)$. - Fluorescence $\left(\mathrm{CHCl}_{3}\right): \lambda_{\max }=533 \mathrm{~nm}, 574$. MS (70 eV): $\mathrm{m} / \mathrm{z}(\%)=476(5), 475(28), 474(87)[\mathrm{M}+], 457(5), 445(5), 433(6), 432(17), 415(6), 404$ (6), $391(21), 390(70), 373(5), 346(6), 345$ (9), $275(5), 174(17), 146(5) 145(7), 104(6), 92(4), 91(10)$, $84(5), 77(5), 76(5), 69(6), 67(5), 57(15), 56(5), 55$ (12), 44 (58), 43 (19), 42 (7), 41 (19), 39 (12). Solubility $\left(\mathrm{CHCl}_{3} / 20^{\circ} \mathrm{C}\right): 5.3 \mathrm{mg} / 100 \mathrm{ml}$.

$\mathrm{C}_{30} \mathrm{H}_{22} \mathrm{~N}_{2} \mathrm{O}_{4}$ calcd. C $75.94 \mathrm{H} 4.67 \mathrm{~N} 5.90$

(474.5) found $\mathrm{C} 76.02 \mathrm{H} 4.71 \mathrm{~N} 5.96$

\section{$N, N^{\prime}$-Di(1-butyl)perylene-3,4:9, 10-bis(dicarboximid) (3 a) [27]}

$0.43 \mathrm{~g}(6.0 \mathrm{mmol}) 1$-Butylamin, reaction time $1 \mathrm{~h}$, purification by extractive [8] recrystallisation from toluene and cyclopentanone. Yield $0.54 \mathrm{~g}(42 \%)$, dark brown powder $-\mathrm{mp} .>350^{\circ} \mathrm{C}, \mathrm{R}_{\mathrm{f}}$ (silica gel/ $\left.\mathrm{CHCl}_{3}\right)=0.26$. - IR $(\mathrm{KBr}): \tilde{\nu}=2960 \mathrm{~cm}^{-1} \mathrm{~m}, 2932 \mathrm{w}, 2871 \mathrm{w}, 2860 \mathrm{w}, 1695 \mathrm{~s}, 1658 \mathrm{~s}, 1616 \mathrm{w}$, $1594 \mathrm{~s}, 1579 \mathrm{~m}, 1507 \mathrm{w}, 1440 \mathrm{~m}, 1404 \mathrm{~m}, 1374 \mathrm{w}, 1341 \mathrm{~m}, 1289 \mathrm{w}, 1272 \mathrm{w}, 1243 \mathrm{w}, 1197 \mathrm{w}, 1180 \mathrm{w}$, 1155 w, 1127 w, 1114 w, 1088 w, 1021 w, 981 w, 972 w, 923 w, 850 w, 810 s, 794 w, 746 w, 626 w, 589 w. - UV $\left(\mathrm{CHCl}_{3}\right): \lambda_{\max }(\epsilon)=457 \mathrm{~nm}(18690), 488(50100), 525(83050)$. - Flourescence $\left(\mathrm{CHCl}_{3}\right)$ : $\lambda_{\max }=532 \mathrm{~nm}, 572 .-\mathrm{MS}(70 \mathrm{eV}): \mathrm{m} / \mathrm{z}(\%)=504(6), 503(36), 502(100)[\mathrm{M}+], 486(8), 485(25)$, 459 (5), 447 (8), $446(10), 430(5), 429$ (13), 405 (8), 404 (27), 392 (5), 391 (17), 390 (51), $376(5), 373$ (7), $346(7), 345(10), 275(5), 55(6), 44(11), 41(8)$. - Solubility $\left(\mathrm{CHCl}_{3} / 20^{\circ} \mathrm{C}\right): 8.9 \mathrm{mg} / 100 \mathrm{ml}$.

$\mathrm{C}_{32} \mathrm{H}_{26} \mathrm{~N}_{2} \mathrm{O}_{4}$ calcd. C $76.48 \mathrm{H} 5.21 \mathrm{~N} 5.57$

(502.6) found $\mathrm{C} 76.59 \mathrm{H} 5.31 \mathrm{~N} 5.49$.

\section{N,N'Di(1-pentyl)perylene-3,4:9, 10-bis(dicarboximid) (3 b) [28]}

$0.60 \mathrm{~g}(6.0 \mathrm{mmol}) 1-$ Pentylamine, reaction time $1 \mathrm{~h}$, purification by extractive [8] recrystallisation from toluene. Yield $1.3 \mathrm{~g}(96 \%)$, dark brown powder $-\mathrm{mp} .>350^{\circ} \mathrm{C}, \mathrm{R}_{\mathrm{f}}$ (silica gel $\left./ \mathrm{CHCl}_{3}\right)=0.28$. $-\mathrm{IR}$ $(\mathrm{KBr}): \tilde{\nu}=2956 \mathrm{~cm}^{-1} \mathrm{~m}, 2932 \mathrm{~s}, 2861 \mathrm{~m}, 1696 \mathrm{~s}, 1658 \mathrm{~s}, 1616 \mathrm{w}, 1594 \mathrm{~s}, 1579 \mathrm{~m}, 1507 \mathrm{w}, 1467$ w, $1457 \mathrm{w}, 1440 \mathrm{~m}, 1404 \mathrm{~m}, 1379 \mathrm{w}, 1343 \mathrm{~m}, 1300 \mathrm{w}, 1260 \mathrm{w}, 1177 \mathrm{w}, 1155 \mathrm{w}, 1127 \mathrm{w}, 1094 \mathrm{w}, 1013 \mathrm{w}$, $852 \mathrm{w}, 810 \mathrm{~s}, 795 \mathrm{w}, 747 \mathrm{~m}, 628 \mathrm{w}, 591 \mathrm{w} .-\mathrm{UV}\left(\mathrm{CHCl}_{3}\right): \lambda_{\max }(\epsilon)=457.5 \mathrm{~nm}(18420), 488(50430), 524.5$ $(84020)$. - Fluorescence $\left(\mathrm{CHCl}_{3}\right): \lambda_{\max }=534 \mathrm{~nm}, 573$. - MS $(70 \mathrm{eV}): \mathrm{m} / \mathrm{z}(\%)=532(7), 531(35), 530$ (100) [M+], $514(5), 513(12), 473(5), 462(3), 461$ (11), $460(9), 443(6), 418(5), 405$ (7), 404 (21), $392(5)$, $391(15), 390(35), 373(5), 346(5), 345(7)$. - Solubility $\left(\mathrm{CHCl}_{3} / 20^{\circ} \mathrm{C}\right): 47 \mathrm{mg} / 100 \mathrm{ml}$.

$\mathrm{C}_{34} \mathrm{H}_{30} \mathrm{~N}_{2} \mathrm{O}_{4}$ calcd. C $76.96 \mathrm{H} 5.70 \mathrm{~N} 5.28$

(530.6) found C $77.04 \mathrm{H} 5.60 \mathrm{~N} 5.28$. 


\section{$N, N^{\prime}$-Di(I-nonyl)perylene-3,4:9,10-bis(dicarboximid) (3f)}

$1.72 \mathrm{~g}(12.0 \mathrm{mmol}) 1$-Nonylamine, reaction time $1 \mathrm{~h}$, purification by extractive [8] recrystallisation from toluene and cyclopentanone. Yield $2.13 \mathrm{~g}(65 \%)$, dark brown needles $-\mathrm{mp} .343-344{ }^{\circ} \mathrm{C}, \mathrm{R}_{\mathrm{f}}$ (silica gel/ $\left.\mathrm{CHCl}_{3}\right)=0.45$. - IR $(\mathrm{KBr}): \tilde{\nu}=2953 \mathrm{~cm}^{-1} \mathrm{w}, 2929 \mathrm{~m}, 2854 \mathrm{w}, 1696 \mathrm{~s}, 1658 \mathrm{~s}, 1616 \mathrm{w}, 1594 \mathrm{~s}$, $1578 \mathrm{~m}, 1506 \mathrm{w}, 1467 \mathrm{w}, 1456 \mathrm{w}, 1440 \mathrm{w}, 1405 \mathrm{w}, 1380 \mathrm{w}, 1343 \mathrm{~m}, 1298 \mathrm{w}, 1276 \mathrm{w}, 1254 \mathrm{w}, 1091 \mathrm{w}$, $853 \mathrm{w}, 846 \mathrm{w}, 810 \mathrm{~m}, 794 \mathrm{w}, 747 \mathrm{~m}, 725 \mathrm{w}, 630 \mathrm{w}, 591 \mathrm{w}$. $-\mathrm{UV}\left(\mathrm{CHCl}_{3}\right): \lambda_{\max }(\epsilon)=457.5 \mathrm{~nm}(19030)$, $488.5(51430), 525(85370)$. - Fluorescence $\left(\mathrm{CHCl}_{3}\right): \lambda_{\max }=532 \mathrm{~nm}, 573$. $-\mathrm{MS}(70 \mathrm{eV}): \mathrm{m} / \mathrm{z}(\%)=$ $644(10), 643(46), 642(100)[\mathrm{M}+], 625(9), 530(5), 529(8), 518(6), 517(18), 516(7), 405(8), 404(18)$, $392(7), 391(18), 390(25), 373(5), 55(5), 44(33), 41(6)$. - Solubility $\left(\mathrm{CHCl}_{3} / 20^{\circ} \mathrm{C}\right): 11 \mathrm{mg} / 100 \mathrm{ml}$.

$\mathrm{C}_{42} \mathrm{H}_{46} \mathrm{~N}_{2} \mathrm{O}_{4}$ calcd. C $78.47 \mathrm{H} 7.21 \mathrm{~N} 4.36$

(642.8) found $\mathrm{C} 78.58 \mathrm{H} 7.34 \mathrm{~N} 4.13$.

\section{$N, N^{\prime}$-Di(1-tetradecyl)perylene-3,4:9, 10-bis(dicarboximid)}

$2.56 \mathrm{~g}(12.0 \mathrm{mmol}) 1-T e t r a d e c y l a m i n e$, reaction time $1 \mathrm{~h}$, purification by extractive [8] recrystallisation from toluene and cyclopentanone. Yield $2.04 \mathrm{~g}(51 \%)$, black needles $-\mathrm{mp} .327-338^{\circ} \mathrm{C}, \mathrm{R}_{\mathrm{f}}$ (silica $\left.\mathrm{gel} / \mathrm{CHCl}_{3}\right)=0.57 .-\mathrm{IR}(\mathrm{KBr}): \tilde{v}=2954 \mathrm{~cm}^{-1} \mathrm{~m}, 2924 \mathrm{~s}, 2851 \mathrm{~m}, 1697 \mathrm{~m}, 1697 \mathrm{~s}, 1658 \mathrm{~s}$, $1615 \mathrm{w}, 1594 \mathrm{~s}, 1580 \mathrm{~m}, 1510 \mathrm{w}, 1467 \mathrm{~m}, 1440 \mathrm{~m}, 1405 \mathrm{~m}, 1379 \mathrm{~m}, 1344 \mathrm{~m}, 1302 \mathrm{w}, 1282 \mathrm{w}, 1261 \mathrm{~m}$, $1249 \mathrm{~m}, 1186 \mathrm{w}, 1160 \mathrm{w}, 1132 \mathrm{w}, 1091 \mathrm{~m}, 1015 \mathrm{w}, 1008 \mathrm{w}, 987 \mathrm{w}, 975 \mathrm{w}, 857 \mathrm{w}, 848 \mathrm{w}, 809 \mathrm{~s}, 796 \mathrm{w}$, $747 \mathrm{~s}, 728 \mathrm{w}, 635 \mathrm{w}, 594 \mathrm{w}$. - UV $\left(\mathrm{CHCl}_{3}\right): \lambda_{\max }(\epsilon)=458 \mathrm{~nm}(19070), 488.5(51300), 525(85120)$. Fluorescence $\left(\mathrm{CHCl}_{3}\right): \lambda_{\max }=533 \mathrm{~nm}, 573 .-\mathrm{MS}(70 \mathrm{eV}): \mathrm{m} / \mathrm{z}(\%)=785(16), 784(54), 783(100)$ $[\mathrm{M}+$ ], $766(13), 755(8), 588(9), 587(20), 586(7), 418(5), 417(5), 405(12), 404$ (17), $403(5), 392(8)$, 391 (19), 390 (23), $373(5), 57(5), 55(5), 44(8), 43$ (7), 41 (5). - Solubility $\left(\mathrm{CHCl}_{3}\right): 5.4 \mathrm{mg} / 100 \mathrm{ml}$.

$\mathrm{C}_{52} \mathrm{H}_{66} \mathrm{~N}_{2} \mathrm{O}_{4}$ calcd. C $79.76 \mathrm{H} 8.49 \mathrm{~N} 3.58$

(783.1) found $\mathrm{C} 80.01 \mathrm{H} 8.52 \mathrm{~N} 3.47$.

\section{$N, N^{\prime}$-Di(1-hexadecyl)perylene-3,4:9, 10-bis(dicarboximid) (3 k)}

$2.90 \mathrm{~g}(12.0 \mathrm{mmol}) 1$-Hexadecylamine, reaction time $1 \mathrm{~h}$, purification by extractive [8] recrystallisation from toluene and cyclopentanone. Yield $2.13 \mathrm{~g}(50 \%)$, black needles $-\mathrm{mp} .312-313^{\circ} \mathrm{C}, \mathrm{R}_{\mathrm{f}}$ (silica $\left.\mathrm{gel} / \mathrm{CHCl}_{3}\right)=0.62$. IR $(\mathrm{KBr}): \tilde{\nu}=2958 \mathrm{~cm}^{-1} \mathrm{~m}, 2924 \mathrm{~s}, 2850 \mathrm{w}, 1697 \mathrm{~s}, 1658 \mathrm{~s}, 1612 \mathrm{w}$, $1594 \mathrm{~s}, 1580 \mathrm{~m}, 1507 \mathrm{w}, 1467 \mathrm{~m}, 1457 \mathrm{w}, 1442 \mathrm{~m}, 1405 \mathrm{~m}, 1379 \mathrm{~m}, 1344 \mathrm{~m}, 1302 \mathrm{w}, 1286 \mathrm{w}, 1267 \mathrm{w}$, $1253 \mathrm{~m}, 1245 \mathrm{w}, 1189 \mathrm{w}, 1160 \mathrm{w}, 1132 \mathrm{w}, 1091 \mathrm{~m}, 1018 \mathrm{w}, 987 \mathrm{w}, 856 \mathrm{w}, 848 \mathrm{w}, 809 \mathrm{~s}, 796 \mathrm{w}, 747 \mathrm{~s}, 728 \mathrm{w}$, $634 \mathrm{w}, 595 \mathrm{w}$. - UV $\left(\mathrm{CHCl}_{3}\right): \lambda_{\max }(\epsilon)=457.5 \mathrm{mn}(18340), 488(49770), 524.5(82470)$. - Fluorescence $\left(\mathrm{CHCl}_{3}\right): \lambda_{\max }=533 \mathrm{~nm}, 573$. - MS $(70 \mathrm{eV}): \mathrm{m} / \mathrm{z}(\%)=841(19), 840(61), 839(100)[\mathrm{M}+], 822(6)$, $616(9), 615(20), 614$ (6), $418(5), 417$ (6), 405 (14), 404 (16), 403 (5), 392 (7), 391 (19), $390(21), 83(5)$, $69(6), 57(10), 55(9), 44(8), 43(12), 41(9)$. - Solubility $\left(\mathrm{CHCl}_{3}\right): 6.0 \mathrm{mg} / 100 \mathrm{ml}$.

$\mathrm{C}_{56} \mathrm{H}_{74} \mathrm{~N}_{2} \mathrm{O}_{4}$ calcd. C $80.15 \mathrm{H} 8.89 \mathrm{~N} 3.34$

(839.2) found $\mathrm{C} 80.35 \mathrm{H} 8.93 \mathrm{~N} 3.24$.

\section{N,N'-Di(I-octadecyl)perylene-3,4:9,10-bis(dicarboximid) (3 m) [29]}

$2.39 \mathrm{~g}(12.0 \mathrm{mmol}) 1-$ Octadecylamine, reaction time $1 \mathrm{~h}$, purification by extractive [8] recrystallisation from toluene. Yield $1.46 \mathrm{~g}(38 \%)$, black needles $-\mathrm{mp} .303-304^{\circ} \mathrm{C}, \mathrm{R}_{\mathrm{f}}\left(\right.$ silica gel $\left./ \mathrm{CHCl}_{3}\right)=0.78$. IR $(\mathrm{KBr}): \tilde{\nu}=2951 \mathrm{~cm}^{-1} \mathrm{~m}, 2924 \mathrm{~s}, 2850 \mathrm{w}, 1697 \mathrm{~s}, 1658 \mathrm{~s} .1594 \mathrm{~s}, 1578 \mathrm{~m}, 1507 \mathrm{w}, 1467 \mathrm{~m}$, $1440 \mathrm{~m}, 1406 \mathrm{~m}, 1380 \mathrm{~m}, 1344 \mathrm{~m}, 1258 \mathrm{~m}, 1246 \mathrm{~m}, 1178 \mathrm{w}, 1157 \mathrm{w}, 1129 \mathrm{w}, 1091 \mathrm{~m}, 854 \mathrm{w}, 846 \mathrm{w}$, $809 \mathrm{~m}, 794 \mathrm{w}, 747 \mathrm{~m}, 725 \mathrm{w}, 631 \mathrm{w} .-\mathrm{UV}\left(\mathrm{CHCl}_{3}\right): \lambda_{\max }(\epsilon)=458.5 \mathrm{~nm}(18500), 489$ (50 800), 525 (84930). - Fluorescence $\left(\mathrm{CHCl}_{3}\right): \lambda_{\max }=534 \mathrm{~nm}, 576$. - MS $(70 \mathrm{eV}): \mathrm{m} / \mathrm{z}(\%)=898(5), 897(21)$, $896(65), 895(100)[M+], 894(5), 878(6), 867$ (7), $644(8), 643(17), 642(6), 417(5), 405(11), 404(12)$, $392(5), 391(15), 390(16)$. - Solubility $\left(\mathrm{CHCl}_{3}\right): 1.8 \mathrm{mg} / 100 \mathrm{ml}$.

$\mathrm{C}_{60} \mathrm{H}_{82} \mathrm{~N}_{2} \mathrm{O}_{4}$ calcd. C $80.49 \mathrm{H} 9.23 \mathrm{~N} 3.13$

(895.3) found $\mathrm{C} 80.32 \mathrm{H} 9.21 \mathrm{~N} 3.26$.

\section{$N, N^{\prime}$-Di(I-heptyloctyl)perylene-3,4:9,10-bis(dicarboximid) (2 e)}

$2.73 \mathrm{~g}(12.0 \mathrm{mmol}) 1$-Heptyloctylamine [30], $10 \mathrm{~g}$ imidazol, reaction time $2 \mathrm{~h}$, purification by coloumn chromatography with petrol ether $30 / 50$ and silica gel and low temperature crystallisation from n-pentane at $-30^{\circ} \mathrm{C}$. Yield $2.70 \mathrm{~g}(66 \%)$, orange rosetts (high temperature modification as a red powder) mp. $129^{\circ} \mathrm{C}$, crystal transformation $50-60^{\circ}, \mathbf{R}_{\mathrm{f}}$ (silica gel $\left./ \mathrm{CHCl}_{3}\right)=0.85-\operatorname{IR}(\mathrm{KBr}): \tilde{\nu}=$ $2955 \mathrm{~cm}^{-1}$ s, $2925 \mathrm{~s} .2855 \mathrm{~s}, 1699 \mathrm{~s}, 1660 \mathrm{~s}, 1594 \mathrm{~s}, 1579 \mathrm{~m}, 1508 \mathrm{w}, 1483 \mathrm{w} 1467 \mathrm{~m}, 1458 \mathrm{~m}, 1435 \mathrm{~m}$, 1406 s, 1378 w, $1352 \mathrm{~m}, 1338$ s, $1255 \mathrm{~m}, 1209 \mathrm{w}, 1174 \mathrm{~m}, 1125 \mathrm{w}, 1108 \mathrm{w}, 964 \mathrm{w}, 865 \mathrm{w}, 856 \mathrm{w}, 851 \mathrm{~m}$, 
$825 \mathrm{w}, 809 \mathrm{~m}, 796 \mathrm{w}, 747 \mathrm{~m}, 724 \mathrm{w}$. - UV $\left(\mathrm{CHCl}_{3}\right): \lambda_{\max }(\epsilon)=458 \mathrm{~nm}(18670), 489(51460), 525.5$ (86040); (n-heptane): $\lambda_{\max }(\epsilon)=448.5 \mathrm{~nm}(20940), 479(55230), 514.5$ (93540). - Fluorescence $\left(\mathrm{CHCl}_{3}\right): \lambda_{\max }=534 \mathrm{~nm}, 576 ;$ (n-heptane) $: \lambda_{\max }=518 \mathrm{~nm}, 558$. Solid state fluorescence (orange modification): $\lambda_{\max }=587 \mathrm{~nm}, 625$. - Solid state fluorescence (red modification): $\lambda_{\max }=642 \mathrm{~nm}$. $-{ }^{1} \mathrm{H}-\mathrm{NMR}$ $\left(\mathrm{CDCl}_{3} / \mathrm{TMS}\right): \delta=0.83(\mathrm{~m}, 12 \mathrm{H}), 1.25(\mathrm{~m}, 40 \mathrm{H}), 2.00(\mathrm{~m}, 8 \mathrm{H}), 5.18(\mathrm{~m}, 2 \mathrm{H}), 8.50(\mathrm{~m}, 8 \mathrm{H}) .-{ }^{13} \mathrm{C}-$ NMR $\left(\mathrm{CDCl}_{3}\right): \delta=14.00,22.57,26.99,29.20,29.51,31.78,32.38,54.77,122.80,123.52,126.25$, $129.43,131.25,134.25,163.84$. $-\mathrm{MS}(70 \mathrm{eV}): \mathrm{m} / \mathrm{z}(\%)=812(18), 811(58), 810(100)[\mathrm{M}+], 794(5)$, $793(8), 602(16), 601(40), 600(41), 403(5), 393(5), 392(21), 391(57), 390(75), 373(8)$. - Solubility (n-heptane $/ 20^{\circ} \mathrm{C}$ ): $0.59 \mathrm{~g} / 100 \mathrm{ml}$.

$\mathrm{C}_{54} \mathrm{H}_{70} \mathrm{~N}_{2} \mathrm{O}_{4}(811.2) \quad$ calcd. C $79.96 \mathrm{H} 8.70 \mathrm{~N} 3.45$

orange modification found $\mathrm{C} 80.32 \mathrm{H} 8.63 \mathrm{~N} 3.38$.

\section{$N, N^{\prime}$-Di(1-octylnonyl)perylene-3,4:9, 10-bis(dicarboximid) (2 f)}

$3.80 \mathrm{~g}$ (12.0 mmol) 1-Octylnonylamine [31], reaction time $2 \mathrm{~h}$, purification by column chromatography with chloroforme and silica gel, a second chromatography with petrol ether and silica gel and a low temperature recrystallisation from n-pentane at $-30^{\circ} \mathrm{C}$. Yield $2.9 \mathrm{~g}(66 \%)$, red brown rhombes - mp. $102-103^{\circ} \mathrm{C}$, crystal transformation several degrees below melting point, $\mathrm{R}_{\mathrm{f}}\left(\right.$ silica gel $\left./ \mathrm{CHCl}_{3}\right)=0.82$. - IR $(\mathrm{KBr}): \tilde{\nu}=2955 \mathrm{~cm}^{-1} \mathrm{~s}, 2926 \mathrm{~s}, 2854 \mathrm{~s}, 1697 \mathrm{~s}, 1651 \mathrm{~s}, 1579 \mathrm{~m}, 1507 \mathrm{w}, 1484 \mathrm{w}, 1467 \mathrm{~m}$, $1457 \mathrm{~m}, 1435 \mathrm{~m}, 1406 \mathrm{~s}, 1377 \mathrm{w}, 1353 \mathrm{~m}, 1339 \mathrm{~s}, 1253 \mathrm{~m}, 1210 \mathrm{w}, 1172 \mathrm{~m}, 1125 \mathrm{w}, 1109 \mathrm{w}, 967 \mathrm{w}, 860 \mathrm{w}$, $850 \mathrm{w}, 810 \mathrm{~m}, 795 \mathrm{w}, 747 \mathrm{~m}, 723 \mathrm{w}$. - UV $\left(\mathrm{CHCl}_{3}\right): \lambda_{\max }(\epsilon)=458.5 \mathrm{~nm}(18710), 489.5(51550), 526$ (85650); (n-heptane): $\lambda_{\max }(\epsilon)=448.5 \mathrm{~nm}$ (20190), 479 (53950), 515 (91770). - Fluorescence $\left(\mathrm{CHCl}_{3}\right): \lambda_{\max }=534 \mathrm{~nm}, 576 ;$ (n-heptane): $\lambda_{\max }=523.5 \mathrm{~nm}, 558$. Solid state fluorescence (orange modification): $\lambda_{\max }=585 \mathrm{~nm}, 595 \mathrm{sh}, 625 \mathrm{sh}$. - Solid state fluorescence (red modification): $\lambda_{\max }=$ $608 \mathrm{~nm}$. - ${ }^{1} \mathrm{H}-\mathrm{NMR}\left(\mathrm{CDCl}_{3} / \mathrm{TMS}\right): \delta=0.95(\mathrm{~m}, 12 \mathrm{H}), 1.23(\mathrm{~m}, 48 \mathrm{H}), 2.00(\mathrm{~m}, 8 \mathrm{H}), 5.10(\mathrm{~m}, 2 \mathrm{H})$, $8.48(\mathrm{~m}, 8 \mathrm{H}), \quad-{ }^{13} \mathrm{C}-\mathrm{NMR}\left(\mathrm{CDCl}_{3}\right): \delta=14.03,22.60,26,99,29.23,29.51,31.81,32.38,54.77$, $122.80,123.52,125.28,129.46,131.31,134.28,164.11$. $-\mathrm{MS}(70 \mathrm{eV}): \mathrm{m} / \mathrm{z}(\%)=869(8), 868(27)$, $867(42)[\mathrm{M}+], 854(9), 853(15), 850(5), 812(8), 811(14), 630(14), 629(33), 628(29), 615(6), 614(5)$, $601(10), 600(9), 403(6), 393(7), 392(29), 391(81), 390(100), 373(9), 238(5), 111(8), 98(15), 97(17)$, $85(6), 84(10), 83(22), 81(5), 71(11), 70(14), 69(24), 67(8), 57(19), 56(13), 55(32), 54(6), 44(8), 43$ (24), $42(6), 41(22), 39(6)$. - Solubility (n-heptane $/ 20^{\circ} \mathrm{C}$ ): $0.30 \mathrm{~g} / 100 \mathrm{ml}$.

$\mathrm{C}_{58} \mathrm{H}_{78} \mathrm{~N}_{2} \mathrm{O}_{4}(867.3) \quad$ calcd. C $80.33 \mathrm{H} 9.06 \mathrm{~N} 3.23$

orange modification found C $80.79 \mathrm{H} 9.04 \mathrm{~N} 3.34$.

$X$-ray structure analysis of 7 low temperature modification: $\mathrm{C}_{58} \mathrm{H}_{78} \mathrm{~N}_{2} \mathrm{O}_{4}, \mathrm{Mr}=867.28, \mathrm{a}=1760.9(6)$, $\mathrm{b}=1929.1(7), \mathrm{c}=1404.2(4) \mathrm{pm}, \alpha=104.04(3)^{\circ}, \beta=113.12(3)^{\circ}, \gamma=100.67(3)^{\circ}, \mathrm{V}=4039(2) \cdot 10^{-6}$ $\mathrm{pm}^{-3}, \mathrm{Z}=3, \mathrm{~d}_{\mathrm{calc}}=1.070 \mathrm{~g} \cdot \mathrm{cm}^{-3}$, crystal system triclinic, space group $\mathrm{P} 1$ - data collection: diffractometer Nicolet $\mathrm{R} 3 \mathrm{~m} / \mathrm{V}$, radiation $\mathrm{Mo} \mathrm{K}_{\alpha}$, monochromator graphite, single crystal $0.45 \times 0.95 \times$ $0.15 \mathrm{~mm}^{-3}$, data collection mode Wyckhoffscan, $\Theta$ range $1.75-27.5^{\circ}, 18634$ measured reflections and 4304 as observed ( $I \leq 3 \sigma(F)$ ), lin abs. coeff. $0.06 \mathrm{~mm}^{-1}$, abs. correction Psi -scan, structural analysis and refinement: solution by direct phase determination, method of refinement full matrix isotropical LSQ, parameter $/ F_{o}$ ratio $0.089, R=0.262$, program used Nicolet SHELXTL PLUS.

\section{$N, N^{\prime}$-Di(1-nonyldecyl)perylene-3,4:9, 10-bis(dicarboximid) (2 g)}

$5.7 \mathrm{~g}(18.0 \mathrm{mmol}) 1-$ Nonyldecylamine [31], reaction time $2 \mathrm{~h}$, purification by column chromatography with chloroforme and silica gel, a second chromatography with $n$-pentane and silica gel and a low temperature recrystallisation from n-pentane at $-30^{\circ} \mathrm{C}$. Yield $4.7 \mathrm{~g}(68 \%)$, red powder $-\mathrm{mp} .97^{\circ} \mathrm{C}, \mathrm{R}_{\mathrm{f}}$ (silica gel $\left./ \mathrm{CHCl}_{3}\right)=0.88$. IR $(\mathrm{KBr}): \tilde{\nu}=2955 \mathrm{~cm}^{-1} \mathrm{~m}, 2925 \mathrm{~s}, 2854 \mathrm{~s}, 1697 \mathrm{~s}, 1653 \mathrm{~s}, 1617 \mathrm{~W}$, $1595 \mathrm{~s}, 1579 \mathrm{~m}, 1507 \mathrm{w}, 1467 \mathrm{~m}, 1457 \mathrm{~m}, 1436 \mathrm{~m}, 1406 \mathrm{~m}, 1377 \mathrm{w}, 1353 \mathrm{~m}, 1340 \mathrm{~s}, 1255 \mathrm{~m}, 1211 \mathrm{w}$, $1174 \mathrm{w}, 1125 \mathrm{w}, 1112 \mathrm{w}, 958 \mathrm{w}, 852 \mathrm{w}, 811 \mathrm{~m}, 795 \mathrm{w}, 747 \mathrm{~m}, 721 \mathrm{w}$. - UV $\left(\mathrm{CHCl}_{3}\right): \lambda_{\max }(\epsilon)=457.5 \mathrm{~nm}$ (19910), 488.5 (52720), 524.5 (87080); (n-heptane): $\lambda_{\max }(\epsilon)=448 \mathrm{~nm}(21210), 478(55060), 514$ (93830). - Fluorescence $\left(\mathrm{CHCl}_{3}\right): \lambda_{\max }=532.5 \mathrm{~nm}, 574.5 ;$ (n-heptane): $\lambda_{\max }=519.5 \mathrm{~nm}, 558.5$. Solid state fluorescence: $\lambda_{\max }=612 \mathrm{~nm}$. $-{ }^{1} \mathrm{H}-\mathrm{NMR}\left(\mathrm{CDCl}_{3} / \mathrm{TMS}\right): \delta=0.9(\mathrm{~m}, 12 \mathrm{H}), 1.3(\mathrm{~m}, 56 \mathrm{H})$, $2.1(\mathrm{~m}, 8 \mathrm{H}), 5.2(\mathrm{~m}, 2 \mathrm{H}), 8.7(\mathrm{~m}, 8 \mathrm{H}):-{ }^{13} \mathrm{C}-\mathrm{NMR}\left(\mathrm{CDCl}_{3}\right): \delta=14.1,22.7,27.0,29.3,29.6,30.3$, $31.9,32.4,54.8,75.2,75.4,122.1,123.6,124.0,126.4,129.6,131.3,134.4,164.1,164.2 .-\mathrm{MS}$ $(70 \mathrm{eV}): \mathrm{m} / \mathrm{z}(\%)=925(13.8), 924(41), 923(59)[\mathrm{M}+], 657(29), 656(22), 391(46), 390(51), 266(38)$, $125(27), 111(52), 98(27), 97(93), 85(27), 84(39), 83(100), 82(27), 71(56), 69(87), 67(29), 57(80), 56$ (53), $55(94), 54(24), 43(72)$. - Solubility (n-heptane): $35 \mathrm{~g} / 100 \mathrm{ml}$. 
$\mathrm{C}_{62} \mathrm{H}_{86} \mathrm{~N}_{2} \mathrm{O}_{4}$ calcd. C $80.65 \mathrm{H} 9.39 \mathrm{~N} 3.03$

(922.7) found $\mathrm{C} 80.51 \mathrm{H} 9.61 \mathrm{~N} 3.15$.

\section{$N, N^{\prime}$-Di(1-decylundecyl)perylene-3,4:9,10-bis(dicarboximid) (2 h)}

$1.7 \mathrm{~g}(4.4 \mathrm{mmol}) 1$-decylundecylamine [31] reaction time $1 \mathrm{~h}$, purification by column chromatography with chloroforme and silica gel, a second chromatography with petrol ether $30 / 50$ and silica gel and a low temperature recrystallisation from n-pentane at $-30^{\circ} \mathrm{C}$. Yield $1.34 \mathrm{~g}(31 \%)$, red powder $-\mathrm{mp}$. $95^{\circ} \mathrm{C}, \mathrm{R}_{\mathrm{f}}$ (silica gel $\left./ \mathrm{CHCl}_{3}\right)=0.90$. IR $(\mathrm{KBr}): \tilde{\nu}=2925 \mathrm{~cm}^{-1} \mathrm{~s}, 2854 \mathrm{~s}, 1734 \mathrm{w}, 1697 \mathrm{~s}, 1651 \mathrm{~s}$, $1616 \mathrm{w}, 1595 \mathrm{~s}, 1579 \mathrm{~m}, 1506 \mathrm{w}, 1465 \mathrm{~m}, 1457 \mathrm{~m}, 1406 \mathrm{~m}, 1340 \mathrm{~s}, 1252 \mathrm{~m}, 1211 \mathrm{w}, 1175 \mathrm{w}, 813 \mathrm{~m}, 747 \mathrm{~m}$. - UV $\left(\mathrm{CHCl}_{3}\right): \lambda_{\max }(\epsilon)=468 \mathrm{~nm}(18350), 489(50780), 525(84890) ;\left(\mathrm{n}\right.$-heptane) $: \lambda_{\max }(\epsilon)=449 \mathrm{~nm}$ (19950), $479(53750), 515(91740)$. - Fluorescence $\left(\mathrm{CHCl}_{3}\right): \lambda_{\max }=532 \mathrm{~nm}, 572 ;$ (n-heptane) $: \lambda_{\max }=$ $519 \mathrm{~nm}, 559$. - Solid state fluorescence: $\lambda_{\max }=612 \mathrm{~nm} .-\mathrm{MS}(70 \mathrm{eV}): \mathrm{m} / \mathrm{z}(\%)=980(42), 979(59)$ [M + ], 686 (30), 391 (41), $390(43), 294$ (37), $111(53), 97$ (98), 85 (31), 84 (39), 83 (100), $82(30), 71(47)$, $70(51), 69(84), 67(31), 57(84), 55(91), 43(85), 41$ (67). - Solubility (n-heptane): $4.8 \mathrm{~g} / 100 \mathrm{ml}$.

$\mathrm{C}_{66} \mathrm{H}_{94} \mathrm{~N}_{2} \mathrm{O}_{4}$ calcd. C $80.93 \mathrm{H} 9.67 \mathrm{~N} 2.86$

(978.8) found $\mathrm{C} 81.06 \mathrm{H} 9.64 \mathrm{~N} 2.84$.

\section{N,N'Di(1-dodecyltridecyl)perylene-3,4:9,10-bis(dicarboximid) (2i)}

$2.2 \mathrm{~g}(6.0 \mathrm{mmol}) 1$-Dodecyltridecylamine, reaction time $2 \mathrm{~h}$, purification by column chromatography with chloroforme and silica gel, a second chromatography with petrol ether $30 / 50$ and silica gel and a low temperature recrystallisation from $\mathrm{n}$-pentane at $0{ }^{\circ} \mathrm{C}$. Yield $0.91 \mathrm{~g}(13 \%)$, orange powder $-\mathrm{mp}$. $74.5^{\circ} \mathrm{C}, \mathrm{R}_{\mathrm{f}}$ (silica gel $\left./ \mathrm{CHCl}_{3}\right)=0.90 .-\operatorname{IR}(\mathrm{KBr}): \tilde{y}=2924 \mathrm{~cm}^{-1} \mathrm{~s}, 2853 \mathrm{~s}, 1697 \mathrm{~s}, 1653 \mathrm{~s}$, $1616 \mathrm{w}, 1595 \mathrm{~s}, 1579 \mathrm{~m}, 1507 \mathrm{w}, 1467 \mathrm{~m}, 1436 \mathrm{w}, 1406 \mathrm{~m}, 1340 \mathrm{~s}, 1254 \mathrm{~m}, 1211 \mathrm{w}, 1175 \mathrm{w}, 1125 \mathrm{w}$, $812 \mathrm{~m}, 748 \mathrm{w}, 722 \mathrm{w}$. - UV $\left(\mathrm{CHCl}_{3}\right): \lambda_{\max }(\epsilon)=458 \mathrm{~nm}$ (18 830), 489 (50 790), 525 (84 490); (n-heptane): $\lambda_{\max }(\epsilon)=449 \mathrm{~nm}(20270), 479(53860), 515(91770)$. - Fluorescence $\left(\mathrm{CHCl}_{3}\right): \lambda_{\max }=532 \mathrm{~nm}$, 572; (n-heptane) : $\lambda_{\max }-519 \mathrm{~nm}, 559$. - Solid state fluorescence (orange modification): $\lambda_{\max }=582 \mathrm{~nm}$, $615(\mathrm{sh})$; (red modification): $\lambda_{\max }=623 \mathrm{~nm}$. - ${ }^{\mathrm{l}} \mathrm{H}-\mathrm{NMR}\left(\mathrm{CDCl}_{3}\right): \delta=0.9(\mathrm{~m}, 12 \mathrm{H}), 1.3(\mathrm{~m}, 80 \mathrm{H})$, $2.1(\mathrm{~m}$, br., $8 \mathrm{H}), 5.2(\mathrm{~m}, 2 \mathrm{H}), 8.7(\mathrm{~m}, 8 \mathrm{H}) .-{ }^{13} \mathrm{C}-\mathrm{NMR}\left(\mathrm{CDCl}_{3}\right): \delta=14.1,22.6,27.0,29.3,29.6$, $30.1,31.9,32.4,54.8,122.8,123.6,126.3,129.5,131.3,134.2,163.3,164.0$. - MS $(70 \mathrm{eV}): \mathrm{m} / \mathrm{z}$ $(\%)=1092(19), 1091(47), 1090(56)[M+], 743(33), 742(64), 741(50), 393(38), 392(87), 391(100)$. Solubility (n-heptane): $67 \mathrm{mg} / 100 \mathrm{ml}$.

$\mathrm{C}_{74} \mathrm{H}_{110} \mathrm{~N}_{2} \mathrm{O}_{4}$ calcd. C $81.42 \mathrm{H} 10.16 \mathrm{~N} 2.57$

(1090.9) found $\mathrm{C} 81.51 \mathrm{H} 10.09 \mathrm{~N} 2.76$.

\section{$N, N^{\prime}$-Di(1-hexadecylheptadecyl)perylene-3,4:9,10-bis(dicarboximid) (2 I)}

$8.6 \mathrm{~g}(18 \mathrm{mmol}) 1$-hexadecylheptadecylamine, reaction time $2 \mathrm{~h}$, purification by column chromatography with chloroforme and silica gel, a second chromatography with n-pentane and silica gel and a low temperature recrystallisation from n-pentane at $-30^{\circ} \mathrm{C}$. Yield $1.5 \mathrm{~g}(17 \%)$, red powder $-\mathrm{mp} .97^{\circ} \mathrm{C}, \mathrm{R}_{\mathrm{f}}$ (silica gel $\left./ \mathrm{CHCl}_{3}\right)=0.96$. IR $(\mathrm{KBr}): \tilde{v}=2923 \mathrm{~cm}^{-1} \mathrm{~s}, 2853 \mathrm{~s}, 1697 \mathrm{~m}, 1653 \mathrm{~m}, 1595 \mathrm{~m}, 1577 \mathrm{w}$, $1506 \mathrm{w}, 1467 \mathrm{~m}, 1460 \mathrm{w}, 1437 \mathrm{w}, 1406 \mathrm{~m}, 1340 \mathrm{~m}, 1255 \mathrm{~m}, 1211 \mathrm{w}, 1176 \mathrm{w}, 1129 \mathrm{w}, 968 \mathrm{w}, 812 \mathrm{w}, 800 \mathrm{w}$, $747 \mathrm{w}, 725 \mathrm{w}$. - UV $\left(\mathrm{CHCl}_{3}\right): \lambda_{\max }(\epsilon)=458 \mathrm{~nm}(19087), 489$ (52514), 525.5 (87310); (n-heptane): $\lambda_{\max }(\epsilon)=449.5 \mathrm{~nm}(20045), 480(54940), 515$ (93 970). - Fluorescence $\left(\mathrm{CHCl}_{3}\right): \lambda_{\max }=533 \mathrm{~nm}$, 574.5; (n-heptane): $\lambda_{\max }=518.5 \mathrm{~nm}, 558$. - Solid state fluorescence: $\lambda_{\max }=608 \mathrm{~nm}$. - MS $(70 \mathrm{eV})$ : $\mathrm{m} / \mathrm{z}(\%)=1317(13), 1316(72), 1315(27)[\mathrm{M}+], 856(38), 855(38), 854(67), 853(42), 393(12), 392$ (48), $391(96), 390(100), 253(15), 111(11), 97(20), 85(11), 83(20), 71(14), 69(15), 57(24), 55(15), 43$ (16). - Solubility (n-heptane): $0.13 \mathrm{~g} / 100 \mathrm{ml}$.

$\mathrm{C}_{90} \mathrm{H}_{142} \mathrm{~N}_{2} \mathrm{O}_{4}$ calcd. C $82.13 \mathrm{H} 10.87 \mathrm{~N} 2.13$

(1316.1) found $\mathrm{C} 82.13 \mathrm{H} 11.05 \mathrm{~N} 2.27$.

\section{$N, N^{\prime}$-Di(1-octadecylnonadecyl)perylene-3,4:9,10-bis(dicarboximid) (2 n)}

$5.3 \mathrm{~g}(9.8 \mathrm{mmol}) 1$-Octadecylnonadecylamine, reaction time $1 \mathrm{~h}$, purification by column chromatography with chloroforme and silica gel, a second chromatography with n-pentane and silica gel and a low temperature recrystallisation from n-pentane at $0^{\circ} \mathrm{C}$. Yield $1.2 \mathrm{~g}(19 \%)$, red powder $-\mathrm{mp} .84 .5^{\circ} \mathrm{C}, \mathrm{R}_{\mathrm{f}}$ (silica gel $\left./ \mathrm{CHCl}_{3}\right)=0.94 .-$ IR $(\mathrm{KBr}): \tilde{\nu}=3421 \mathrm{~cm}^{-1} \mathrm{~m}$ br., $2961 \mathrm{~m}, 2920 \mathrm{~s}, 2851 \mathrm{~s}, 1697 \mathrm{~m}$, $1649 \mathrm{~m}, 1595 \mathrm{~m}, 1578 \mathrm{w}, 1506 \mathrm{w}, 1468 \mathrm{~m}, 1438 \mathrm{w}, 1406 \mathrm{~m}, 1340 \mathrm{~m}, 1256 \mathrm{~m}, 1210 \mathrm{w}, 1177 \mathrm{w}, 1125 \mathrm{w}$, $813 \mathrm{~m}, 748 \mathrm{~m}, 720 \mathrm{~s}$. - UV $\left(\mathrm{CHCl}_{3}\right): \lambda_{\max }(\epsilon)=458 \mathrm{~nm}(18180), 489$ (50320), 525 (84 400); (n-heptane): $\lambda_{\max }(\epsilon)=449 \mathrm{~nm}(19160), 479(52370), 515(89350)$. - Fluorescence $\left(\mathrm{CHCl}_{3}\right): \lambda_{\max }=532 \mathrm{~nm}$, 
572; (n-heptane): $\lambda_{\max }=519 \mathrm{~nm}, 560$. - Solid state fluorescence: $\lambda_{\max }=621 \mathrm{~nm}$. - MS $(70 \mathrm{eV}): \mathrm{m} / \mathrm{z}$ $(\%)=1429(3), 1428(7)[\mathrm{M}+], 1427$ (6), 911 (3), $910(3), 909$ (3), $392(8), 391$ (12), 390 (8), 289 (7), 281 (9), $106(40), 57(47), 44$ (100). - Solubility (n-heptane): $26 \mathrm{mg} / 100 \mathrm{ml}$.

$\mathrm{C}_{98} \mathrm{H}_{158} \mathrm{~N}_{2} \mathrm{O}_{4}$ calcd. C $82.41 \mathrm{H} 11.15 \mathrm{~N} 2.23$

(1428.3) found $\mathrm{C} 82.53 \mathrm{H} 11.19 \mathrm{~N} 2.23$.

$N, N^{\prime}$ - Dicyclohexadecylperylene - 3,4:9,10-bis (dicarboximid)

$1.7 \mathrm{~g}(6.0 \mathrm{mmol})$ cyclohexadecylamine hydrochloride [32], reaction time $1 \mathrm{~h}$, purification by extractive [8] recrystallisation from cyclohexane. Yield $0.49 \mathrm{~g}(29 \%)$, brown, brass shining plates $-\mathrm{mp} .>350^{\circ} \mathrm{C}$, (silica gel $\left./ \mathrm{CHCl}_{3}\right)=0.77$. IR $(\mathrm{KBr}): \tilde{\nu}=2928 \mathrm{~cm}^{-1} \mathrm{~s}, 2856 \mathrm{~m}, 1697 \mathrm{~s}, 1658 \mathrm{~s}, 1595 \mathrm{~s}, 1579 \mathrm{~m}$, $1508 \mathrm{w}, 1457 \mathrm{w}, 1437 \mathrm{w}, 1406 \mathrm{~m}, 1339 \mathrm{~s}, 1254 \mathrm{~m}, 1213 \mathrm{w}, 1193 \mathrm{w}, 1173 \mathrm{~m}, 1126 \mathrm{~m}, 1106 \mathrm{w}, 966 \mathrm{~s}, 854 \mathrm{w}$, $811 \mathrm{~m}, 799 \mathrm{w}, 747 \mathrm{~m}$. - UV $\left(\mathrm{CHCl}_{3}\right): \lambda_{\max }(\epsilon)=458.5 \mathrm{~nm}(18780), 489.5 \mathrm{~nm}(51590), 526(86230)$. Fluorescence $\left(\mathrm{CHCl}_{3}\right): \lambda_{\max }=532.5 \mathrm{~nm}, 572.5 .-{ }^{1} \mathrm{H}-\mathrm{NMR}\left(\mathrm{CDCl}_{3} / \mathrm{TMS}\right): \delta=1.39(\mathrm{~m}, 52 \mathrm{H}), 2.10$ $(\mathrm{m}, 8 \mathrm{H}), 5.22(\mathrm{~m}, 2 \mathrm{H}), 8.62(\mathrm{~m}, 8 \mathrm{H}) .-{ }^{13} \mathrm{C}-\mathrm{NMR}\left(\mathrm{CDDl}_{3}\right): \delta=25.60,26.93,30.57,53.01,123.01$, $123.74,126.46,129.55,131.43,134.49,163.96 .-\mathrm{MS}(70 \mathrm{eV}): \mathrm{m} / \mathrm{z}(\%)=837(6), 836(20), 835(33)$, $[\mathrm{M}+], 818(5), 614(16), 613(36), 612(36), 393(6), 392(25), 391(6), 390(100), 373(8), 96(5), 82(6), 81$ $(5), 69(5), 67\left(5\left(, 55(8), 41(5)\right.\right.$. - Solubility $\left(\mathrm{CHCl}_{3}\right): 0.56 \mathrm{~g} / 100 \mathrm{ml}$.

$\mathrm{C}_{56} \mathrm{H}_{70} \mathrm{~N}_{2} \mathrm{O}_{4}$ calcd. $\mathrm{C} 80.54 \mathrm{H} 8.45 \mathrm{~N} 3.35$

(835.2) found $\mathrm{C} 80.70 \mathrm{H} 8.32 \mathrm{~N} 3.48$

\section{References}

[1] Gold, H.; THeidel, H.; Ullmanns Encyclopädie der technischen Chemie, 4 ed., Nr. 17, p. 459, VCH Verlagsgesellschaft, Weinheim 1979.

[2] KrasovitskiI, B.M.; Bolotin, B.M.; Organic Luminescent Materials, 1 ed., VCH Verlagsgesellschaft, Weinheim 1988.

[3] Sachweh, V.; Langhals, H.; Chem. Ber. 123 (1990) 1981.

[4] Potrawa, T.; Langhals, H.; Chem. Ber. 120 (1987) 1075 and ref. cited therein.

[5] Langhals, H.; Potrawa, T.; Nöth, H.; Linti, G.; Angew. Chem. 101 (1989) 497; Angew. Chem. Int. Ed. Engl. 28 (1989) 478

[6] Hoechst AG (Inv. Geissler, and H. REMY) D.O.S. 1.130.099 (24. October 1959), (Chem. Abstr. 57 (1962) P11346f).

[7] Rademacher, A.; Märkle, S.; Langhals, H.; Chem. Ber. 115 (1982) 2927.

[8] Langhals, H.; Chem. Ber. 118 (1985) 4641.

[9] Demmig, S.; Langhals, H.; Chem. Ber. 121 (1988) 225.

[10] SADRAI, M.; BiRd, G.R.; Opt. Commun. 5 (1984) 62.

[11] Ebeid, E.M.; El-Daly, S.A.; Langhals, H.; J. Phys. Chem. 92 (1988) 4565.

[12] LöhmannsRöben, H.-G.; Langhals, H.; Appl. Phys. B 48 (1989) 449.

[13] Langhals, H.; Nachr. Chem. Tech. Lab. 28 (1980) 716 (Chem. Abstr. 95 (1981) R9816q).

[14] Langhals, H.; SOTT, H.; SCHWENDENER, R.A.; D.O.S. 3935257.9 (23. October 1989).

[15] Langhals, H.; KaISER, H.; D.O.S. 4018787.2 (12. Juni 1990).

[16] Aubert, C.; Fúnfschilling, J.; Zschokke-Gränacher, I.; Langhals, H.; Z. Anal. Chem. 320 (1985) 361.

[17] Schwendener, R.A.; TrüB, T.; Schott, H.; Langhals, H.; Barth, R.F.; Groscurth, P.; Hengartner, H.; Biochim. Biophys. Acta 1026 (1990) 69.

[18] Langhals, H.; Demmig, S.; Huber, H.; Spectrochim. Acta 44 A (1988) 1189.

[19] GRASER, F.; HAEDICKE, E.; Liebigs Ann. Chem. 1984, 483.

[20] Graser, F.; Haedicke, E.; Liebigs Ann. Chem. 19801994.

[21] Haedicke, E.; Graser, F.; Acta Crystallogr., Sect. C: Cryst. Struct. Commun. C 42 (1986) 189.

[22] Haedicke, E.; Graser, F.; Acta Crystallogr., Sect. C: Cryst. Struct. Commun. C 42 (1986) 195.

[23] Langhals, H.; Potrawa, T.; D.O.S. 3901988.8 (29. July 1988) (Chem. Abstr. 113 (1990) P $68456 \mathrm{~K})$.

[24] Langhals, H.; Potrawa, T.; Chimia 44 (1990) 62.

[25] LANGHALS, H.; Chem. Ind. (Düsseldorf) 113/6 (1990) 56.

[26] Langhals, H.; Demmig, S.; D.O.S. 4007618.0 (10. March 1990).

[27] Nagao, Y.; TANabe, Y.; Misono, T.; Nippon Kagaku Kaishi, 1979, 528 (Chem. Abstr. 91 (1979) 38468a). 
[28] Nagao, Y.; Misono, T.; Bull. Chem. Soc. Jpn. 54 (1981) 1191.

[29] Farbwerke Hoechst AG (Inv. G. Geissler, H. ReMY), DBP 1130 099, 24.05.1962 (Chem. Abstr. 57 (1962) 11346d).

[30] Barrow, E.T.; Hargreaves, B.M.C.; Page, J.E.; Resuggan, J.C.L.; Robinson, F.A.; J. Chem. Soc. 1947, 197.

[31] Grossi, G.; Jagodic, V.; Comit.Nazl.Energia Nucl. 1964, RT-CHI-16 (Chem. Abstr. 63 (1965) 13112f).

[32] Sicher, J.; Svoboda, M.; Chem. Listy 52 (1958) 1560 (Chem. Abstr. 53 (1959) 1185g).

Bei der Redaktion eingegangen am 25. Februar 1991 bzw. 27. Mai 1991.

Anschr. d. Verf.: Prof. Dr. Heinz Langhals, Dr. Stefan Demmig, Dr. Thomas Potrawa, Universität München, Institut für Organische Chemie,

Karlstraße 23, W-8000 München 2, Bundesrepublik Deutschland 